\title{
HUKUM MENIKAH KETIKA SAKIT YANG MENGHALANGI KEHARMONISAN RUMAH TANGGA ANALISIS PENDAPAT IMAM MALIK BIN ANAS
}

\author{
Robi Rendra Tribuana \\ Penyuluh Agama Islam Kota Pekanbaru \\ rendraroby@yahoo.com
}

\begin{abstract}
Marriage law when a married couple suffers from illness which obstructs harmony in the household becomes one of the very important problems that occur in the household. According to Imam Malik bin Anas, that it is permissible to divorce / cancel the marriage contract if one partner suffers illness that causes illness the husband and wife relationship is uncomfortable, depressed and uneasy, more harm than the benefit, unable to enjoy the beauty of married life, and not achieving the purpose of marriage sakinah mawaddah warohmah. The purpose of this study is to analyze and express the views of Imam Malik bin Anas about the law of marriage when sickness hinders household harmony, analyzes the reasons Imam Malik bin Anas prohibits marriage when sickness obstructs household harmony, and sees its relevance to the current situation. In the research method, this type of research uses library research. Data analysis techniques using content analysis (content analysis) with qualitative methods using descriptive analysis. The results of this study are: First: Pain that eliminates harmony in the household is qiyas or equated with disgrace that causes marriage fasakh. Secondly, the opinion of Imam Malik bin Anas about getting married when sickness that hinders the harmony of the household may be canceled / divorced because of not achieving the purpose of marriage. Third, as for the current condition, that any disease / disability, if it can be recovered or treated without leaving a serious scar, then the disease is considered to be non-existent and has no effect on the contract.
\end{abstract}

Keywords : Marriage Law, Pain that Obstructs Family Harmony, Imam Malik bin Anas

\section{Pendahuluan}

Menurut mazhab Maliki pernikahan adalah: (Abdurrahman.al-Jaziri, 1979, pp. 12-14)

$$
\begin{aligned}
& \text { النكح عقد يتضمن الحكم لاباحة الوطء } \\
& \text { ويتمتع ما فى زوجية بنكحها. }
\end{aligned}
$$

Artinya: "Nikah adalah suatu akad yang mengandung ketentuan hukum semata-mata untuk membolehkan watha' dan menikmati apa saja yang ada pada diri seorang perempuan yang boleh dinikahinya".

Dalam pernikahan terdapat rukun dan syarat pernikahan yang tidak boleh tertinggal.Artinya,dalam sebuah perni kahan tidak sah bila keduanya tidak ada atau tidak lengkap. Keduanya mengandung arti yang berbeda, rukun 
itu adalah sesuatu yang berada di dalam hakikat dan merupakan bagian atau unsur yang mewujudkannya. (Amir.Syarifuddin,2011,p.59)

Sedangkan syarat adalah hal yang menjadi penentu keberadaan sesuatu, dan ia berada di luar hakikat sesuatu tersebut. (Wahbah.az-Zuhaily, 2011, p. 54)

Semua ulama sependapat dalam hal-hal yang terlibat dan yang harus ada dalam suatu pernikahan, yaitu: akad pernikahan, laki-laki yang akan nikah, perempuan yang akan nikah, wali dari mempelai perempuan, saksi yang menyaksikan akad pernikahan, dan mahar atau mas kawin. (Amir.Syarifuddin, 2011)Meskipun pernikahan telah memenuhi seluruh rukun dan syarat yang ditentukan, belum tentu pernikahan tersebut sah, karena masih tergantung lagi pada satu hal, yaitu pernikahan itu telah terlepas dari segala hal yang menghalangi. Halangan pernikahan itu disebut juga dengan larangan pernikahan. (Amir.Syarifuddin, 2011, p. 109)

Ulama berselisih pendapat me ngenai halangan perkawinan orang yang sedang menderita sakit. Imam Malik bin Anas tidak membolehkan nya. (Ibnu.Rusyd, 1990, p. 445)Dalam halangan pernikahan,ada juga beberapa aib nikah yang bisa dijadikan alasan dibatalkannya pernikahan:Di kutip dari Imam Abu Suja' dalam Matan al-Ghayah wa Taqrib:

وترد المرأة عن خمسة عيوب بها شرط

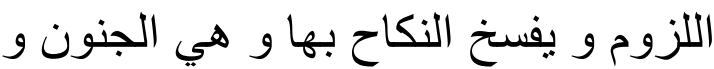
الجذام و البرص و و الرنق و القرن. في الرجل خمسة عيوب و هي الجنون و الجذام و الجب و البرص و العنة Artinya: "Seorang perempuan dibatalkan pernikahannya karena lima aib, yakni: gila, judzam, barash, rataq, dan qarn.Sedangkan lelaki karena lima aib juga, yakni: gila, judzam, barash, al-jubb, dan al-‘anat'. pendapatnya dalam kitab AlMudaw wanah al-Kubro,sebagai berikut:

(Imam.Sahnun.bin.Said.at-Tanwahi, tt, p. 182)

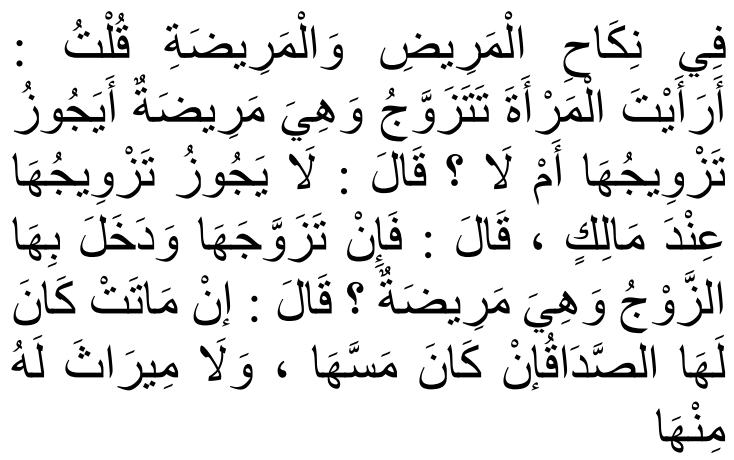

Artinya:"Menikah ketika dalam keadaan sakit: (Aku berkata), "Bagaimana menurut kamu perempuan menikah padahal ia dalam keadaan sakit? Apakah pernikahannya boleh atau tidak"? (Dia berkata), "Tidak boleh menikahi perempuan tersebut menurut pendapat Imam Malik." (Dia berkata), "Maka jika seseorang meni kahinya dan berhubungan badan dengannya padahal perempuan itu sedang sakit”, (Dia berkata), "Jika perempuan itu meninggal maka ba ginya maskawin dan tidak ada wa risan dari perempuan tersebut".

Ini merupakan syarat menurut Malikiyah. Menurut pendapat yang masyhur, tidaklah sah nikah lelaki atau perempuan yang sakit membahayakan diri mereka.Adapun yang dimaksud penyakit membahaya kan adalah penyakit yang biasanya berakhir pada kematian. Jika hal itu terjadi maka pernikahan dibatalkan sekalipun setelah terjadi persengga maan, kecuali jika orang yang sakit tersebut sembuh sebelum pernikah annya dibatalkan. Jika belum terjadi persenggemaan maka si perempuan tidak berhak mendapatkan mahar. (Wahbah.az-Zuhaily, 2011, p. 83) 
Robi Rendra Tribuana : Hukum Menikah Ketika Sakit Yang Menghalangi Keharmonisan Rumah Tangga Analisis Pendapat Imam Malik Bin Anas

DOI:10.24014/af.v18.11.7098

Akan tetapi, jika telah terjadi persanggamaan maka si perempuan berhak mendapatkan mahar yang telah disebutkan. Jika salah satu dari mereka berdua meninggal dunia sebelum dibatalkan, sekalipun setelah terjadi persanggamaan, maka pihak lainnya tidak mewarisinya. Hal itu disebabkan rusaknya adalah mema sukkan ahli waris dalam surat wasiat yang tidak ada sebelum sakit. Akan tetapi, jika suami meninggal dunia sebelum pernikahan dibatalkan dan setelah terjadi persenggamaan, maka si istri mendapat lebih sedikit dari sepertiga tirkah, mahar yang disebut dan mahar mitsil. pernikahan ketika sakit merupakan bentuk pemberian. Pemberian orang yang menderita penyakit tidak ditunaikan melainkan dari sepertiga hartanya. (Wahbah.azZuhaily, 2011, p. 83)

Selain itu, banyak orang yang berumah tangga mengambil keputu san untuk bercerai atau tindakan yang lain dengan jalan berpoligami yang disebabkan oleh salah satu pasangan tidak sanggup memberikan keturunan atau tidak sanggup memenuhi kebutuhan seksual pasang annya dan masing-masing suami/istri merasa jijik terhadap pasangannya dikarenakan menderita penyakit yang sulit untuk disembuhkan sehingga tidak bisa mencapai dari tujuan pernikahan.

Salah satu bukti bahwa cerai merupakan jalan yang ditempuh, di mana seorang istri menggugat cerai suaminya dikarenakan suaminya tidak dapat memberikan keturunan akibat mengidap penyakit lemah syahwat. Dalam penyelesaian berbagai permasalahan yang seperti hal di atas saja dalam masayarakat masih banyak yang belum tahu,terutama pe rmasalahan menikah ketika sakit yang menghalangi keharmonisan rumah tangga lainnya.

\section{TINJAUAN PUSTAKA}

A. Kerangka Teori

1. Pengertian pernikahan

Kata kawin menurut bahasa sama dengan kata nikah, atau kata zawaj. Kata nikah disebut dengan annikh (النكاح) dan az-ziwaj/az-zawajatau az-zijah (الزواج - الزواج - الزيجه). Secara harfiah an-nikh berarti al-wath'u (الوطء), adh- dhammu (الضم) dan al-jam'u (الجمع). Al-wath'u berasal dari kata wath'a yath'u- wath'an (وطا - يطا - وطا), artinya berjalan di atas, melalui, memijak, menginjak memasuki,menaiki,mengga uli dan bersetubuh atau bersenggema. (Ahmad.Warson.al-Munawwir, 1997, p. 1461) Adh-dhammu, yang terambil dari akar kata dhamma - yadhummu dhamman (ضم - يضم - ضما) secara harfiah berarti mengumpulkan, memegang,menggenggam, menyatukan, menggabungkan,menyandarkan,mera ngkul,memeluk,dan menjumlahkan,juga berarti bersikap lunak dan ramah. (Ahmad.Warson.al-Munawwir, 1997)

2. Konsep Imam Malik bin Anas terhadap Hukum Nikah

SecaraAsederhana, mazhabAMa -likiyah mengatakan bahwa nikah aadalah kepemilikan manfaat, karenanya nikah yang sah adalah ketika terkumpul 3 rukunnya, yaitu wali, pengantin dan shigat. (Ahmad.Warson.al-Munawwir, 1997, p. 334) Nikah yang sah itu apabila ketiga syarat utama itu terwujud yaitu: Pertama: terbukanyaAkemungki inan jima' karena inti jima' adalah menumpahkan sperma suami ke rahim sang istri. Kedua, adalah terbukanya kemungkinan terjadinya kehamilan. Ketiga, persalinan kelahiran bayi yang mutlak dari rahim sang istri.

Hukum nikah dalam mazhab Malikiyah wajib, sunah, haram, dan mubah. Menurut mazhab Malikiyah, rukun nikah ada lima yaitu: wali, mahar, 
calon suami, calon istri, dan shighat. (Abdul.al-

Rahman.bin.Muhammad.'Audh.alJaziri, 2001, p. 818)

a. Konsep mahar menurut Imam Malik bin Anas

Menurut Imam Malik bin Anas rukun nikah adalah calon laki-laki,calon perempuan, wali, mahar, dua orang saksi, ijab dan qabul. Adapun pendapat ImamMalik bin Anas tentang mahar sebagai rukun nikah terdapat dalam kitab Al-Muwaththa' adalah sebagai berikut:

(Maulana.Zakariya.al-

Kandahlawi, tt, p. 287)

$$
\text { وصغة أركان النكاح أربعة: ولى, وصداق, ومحل, }
$$

Artinya: "Rukun nikah ada empat, yaitu: wali, mahar, tempat, dan shigat/ ijab qabul'.

Dari peryataan diatas, dapat di simpulkan bahwa Imam Malik bin Anas berpendapat bahwa mahar adalah sebagai rukun nikah.

\section{b. Wali Nikah}

Imam Malik bin Anas tidak membolehkan wanita menikahkan dirinya sendiri, baik gadis maupunjanda. Menurut Malikiyah, urutan wali dalam pernikahan adalah: wali mujbir yaitu ayah dan washi-nya (malik), kemudian setelah wali mujbir yaitu anak laki-laki walaupun dihasilkan dari zina,kemudian anak laki-lakinya anak laki-laki, kemudian ayah (tidak mujbir) dengan syarat ayah dengan cara syara' (de ngan nikah yang sah), saudara lakilaki,saudara laki-lakinya seayah.Waqi ila:saudara laki-laki sekandung,sauda saudara laki-laki seayah,anaknya sa saudara laki-laki sekandung, anak lakilakinya saudara laki-laki seayah, kekemudian kakek dari ayah,paman sekandung,anaknya paman,paman dari saudara laki-laki (am liakh), anaknya paman dari saudara laki-laki (ibnu am liakh),ayahnya kakek, pa- mannya ayah,kemudian perwalian pi ndah kepada hakim akan tetapi dengan syarat tidak diperkenankan meminta bayaran maka apabila memita bayaran tidak boleh menjadi wali dalam pernikahan terebut.

Wali bagi wanita yang telah hamil.Maliki tidak memperbolehkan pernikahannya itu sebelum dia me -lahirkan, tidak dengan lelaki yang menzinahinya atau tidak juga dengan lelaki yanglainnya. hal ini berdasarkan sabda Rasulullah saw.:

(Sulaiman.bin.al-

Asy'asy.bn.Syadid.Abu.Daud.asSijistani, 2002, p. 376)

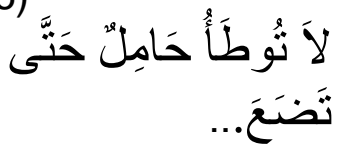

Artinya: "Seorang wanitayang sedang hamil tidak boleh digauli sehingga dia melahirkan..." (HR.Abu Daud)

c. Saksi Nikah

Pendapat Imam Malik bin Anas tentang kedudukan saksi dan masa hadirnya saksi dalam perkawinan didukung dengan dalil (Abu.Hasan.Ali.bin.Umar, tth, p. 344)

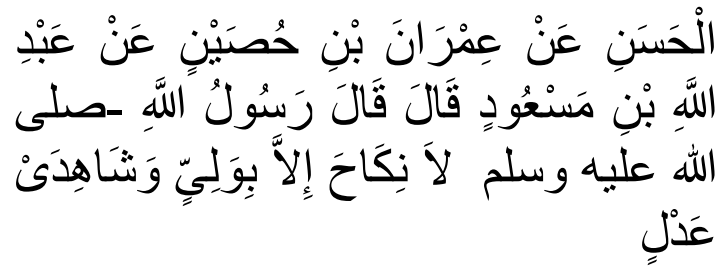

Artinya: "Dari Imron bin Husen dari Abdullah bin Mas'ud Nabi bersabda saw.:'Tiada sah nikah kecuali dengan wali dan dua orang saksi yang adir'. (HR. Dar al-Quthni)

Menurut Imam Malik bin Anas kedudukan saksi berfungsi sebagai syarat sah, sehingga pernikahan tanpa adanya saksi maka hukumnya tetap sah asal diumumkan terlebih dahulu. Sebagaimana hadis berikut: (Abu.Abdullah.Muhamamad.bin.Yazid. bin.Majah.al-Qazuni, tth, p. 90) 
Robi Rendra Tribuana : Hukum Menikah Ketika Sakit Yang Menghalangi Keharmonisan Rumah Tangga Analisis Pendapat Imam Malik Bin Anas

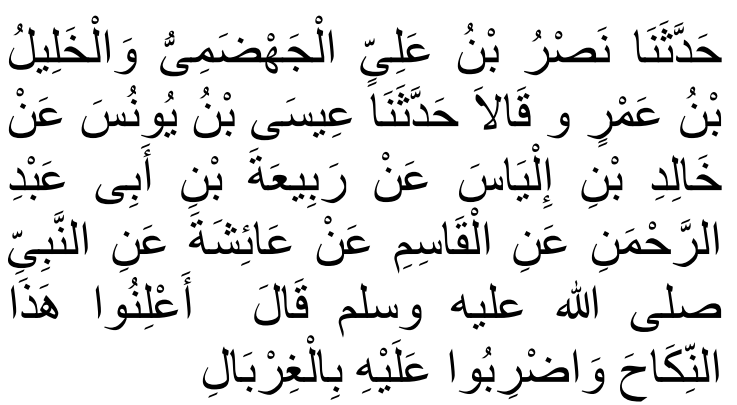

Artinya: "Menyampaikan hadis pada kami Nasr bin al-Juhdomi dan Khalil bin Umar keduanya berkata menyampaikan hadis pada kami Isa bin Yunus dari Kholid bin Ilyas dari Robiah bin Abdurrahman dan dari Qasim dari Aisyah dari Nabi saw. bersabda: Umumkanlah pernikahan dan bunyika nlah genderang'”.(HR. Ibnu Majah)

Imam Malik bin Anas berpendapat bahwa nikah tanpa dihadiri dua orang saksi tetap sah hukumnya, tetapi dengan syarat pernikahan itu harus diumumkan pada khalayak ramai, sehingga secara tidak langsung bahwa Imam Malik bin Anas juga melarang nikah sirri.

\section{d. Fasakh Nikah}

Menurut Imam Malik bin Anas, terjadi pembatalan pekawinan dalam pernikahan fasid.Beliau merinci bebe rapa jenis pernikahan yang tergolong pernikahan yaitu nikah mut'ah dan pernikahan seorang pria dengan wa nita yang mahram (haram dinikahi karena pertalian darah dan hubungan perkawinan).Begitu pula dengan pernikahan seorang wanita tanpa wali, menurut pandangannya bathil.

(Wahbah.az-Zuhaily, al-Fiqhul Islamy, tth, p. 228)

Imam Malik bin Anas berpendapat bahwa cacat yang dapat menyebabkan batalnya perkawinan ada 9 (sembilan) macam, yaitu: gila, kusta, sopak, tahi keluar ketika bersetubuh, kusta yang terang, potong kemaluan, unnah potong 2 buah pelirnya dan lemah kemaluannya karena penyakit. Dari referensi lain, Maliki berpendapat, bahwa penolakan itu bisa terjadi karena empat hal: gila, lepra, kusta, dan penyakit pada kemaluan yang mengahalangi pesetubuhan, baik itu daging yang tumbuh pada kemaluan pada wanita, atau berupa kelamin yang terpotong atau mandul pada laki-laki. (Ibnu.Rusyd, 1990, p. 99)

B. Riwayat Hidup Imam Malik bin Anas

1. Biografi Imam Malik bin Anas Imam Malik bin Anas adalah Imam yang kedua dari Imam mazhab Sunni. Beliau dilahirkan di kota Madinah di negeri $\mathrm{Hijaz}$ tahun 93 $\mathrm{H} / 712 \mathrm{M}$, dan wafat pada hari Ahad, 10 Rabi'ul Awwal 179 H/798 M di Madinah pada masa pemerintahan Abbasiyah di bawah kekuasaan Harun al-Rasyid. Nama lengkapnya ialah Abu Abdillah Malik ibn Anas ibn Malik ibn Abu 'Amir ibn Harits. Ayah Imam Malik bin Anas adalah Anas ibn Malik Abi Amir ibn Abi al-Harist ibn Saad ibn Auf ibn Adi ibn Malik ibn Jazid. (Moenawar.Kholil, 1992, p. 84) Ibunya bernama Siti Aliyah binti Syuraik ibn Abdurahman ibn Syuraik al-Azdiyah. (Huzaemah.Tahido.Yanggo, 1997, p. 103)

2. Guru dan Murid Imam Malik bin Anas.

Dalam bidang sunah ini Imam Malik bin Anas di antaranya ia berguru kepada Nafi Maula ibn Umar dan Ibn Syihab az-Zuhri. IImu fikih ia pelajari diantaranya dari Rabi'ah bin Abdurrahman yang terkenal dengan Rabi'ah ar-Ra'yu, selain itu guru Imam Malik bin Anas adalah Abu az-Zinad, Hasyim bin Urwah, Yahya bin Said alAnshari, Muhammad bin Munkadir, dan lainnya. (Zulkayandri, 2008, p. 51)Di antara para guru Imam Malik bin Anas yang utama tidak kurang dari 700 orang. Di antara sekian banyak 
gurunya itu, terdapat 300 orang yang tergolong ulama tabi'in.

(Huzaemah.Tahido.Yanggo, 1997, p. 104)

Murid-murid Imam Malik bin Anas,antara lain ialah:

(M.Bahri.Ghazali, 1992, p. 65)

:Abu Muhammad Abdullah bin Wahab bin Muslim, wafat tahun 197 H.AbdurRahman bin al-Qashim, wafat tahun 191 H.Asyhab bin Abdul Aziz, wafat tahun 204 H.Asad bin al-Furat, wafat tahun $217 \mathrm{H}$.Abdullah bin Abdul Hakam, wafat tahun 214 H.Sahnun Abdissalam at-Tanuki, wafat tahun 240H.Abu Abdillah Ziyad bin Abdu rrahman al-Kurtubi yang terkenal dengan nama Syahtu (Syahtun), wafat tahun $193 \mathrm{H}$.

Ulama-ulama yang belajar kepada Imam Malik bin Anas dari golongan tabi'in,seperti Al-Zuhri,Ayyub al-Syakhfiyani,Abu al-Aswad,Ra bi'ah ibn Abi Abd. al-Rahman, Yahya ibn Sa'id al-Anshari, Musa ibn Uqbah dan Hisyam ibn Arwah. Dari golongan tabi' al-tabi'in antara lain seperti Nafi' ibn Abi Nu'im, Muhammad ibn Ajlan, Salim ibn Abi Umayyah dan Abu alNadri. Termasuk murid Imam Malik bin Anas juga adalah Imam Syafi'i. Selain itu ada juga Abdullah ibn Wahab, Abd al-Rahman ibn Qasim, Asad ibn al-Furat, bahkan Muhammad Hasan al-Syaibani murid Abu Hanifah juga sempat berguru kepada Imam Malik bin Anas. (Haswir..Muhahmad, 2006, p. 103)

3. Pemikiran dan Karya-karya Imam Malik bin Anas

Karya-karya Imam Malik bin Anas adalah kitab Al-Muwaththa' adalah kumpulan hadis-hadis dan ilmu hadis yang disusun berdasarkan si stematika ilmu fikih dan di dalamnya diterangkan pokok-pokok pikiran Imam Malik bin Anas tentang ilmu fikih, dan pokok-pokok pikiran tersebut disusun dalam bentuk suatu fatwa. Disyarah oleh Muhammad Zakaria al Kandahlawi dengan judul Aujaz alMasalik ila Muwaththa' Malik dan Syarh al-Zarqani 'ala Muwatha' alImam Malik karya Muhammad ibn 'Abd al Baqi al-Zarqani dan Tanwir alHawalik Syarh 'ala Muwatha' Malik karya Jalal al Din 'Abd al-Rahman alSuyuthi al-Syafi'i.

Kitab Al-Mudawwanah al-Kubra karya 'Abd al Salam al-Tanukhi. Merupakan kumpulan risalah yang memuat tidak kurang dari 1.036 masalah dari fatwa Imam Malik bin Anas yang dikumpulkan Asad ibn alFurat al-Naisabury yang berasal dari Tunis. Asad ibn Furat tersebut pernah menjadi murid Imam Malik bin Anas. (Huzaemah.Tahido.Yanggo, 1997, p. 118)

Adapun karya yang lainnya ialah: Bidayah al-Mujtahid wa Nihayah alMuqtashid karya Abu al-Walid Muhammad ibn Ahmad ibn Muhammad ibn Ahmad ibn Rusyd al-Qurthubi alAndalusia. Fath al-Rahim 'ala Figh alImam Mâlik bi al-Adillah karya MuMuhammadA ibn Ahmad. Al-I'tisham karya Abi Ishaq ibn Musa al-Syathibi. Mukhtashar Khalil 'ala Matn al-Risalah li Ibn Abi Zaid al-Qirawani karya Syaikh Abd.al-Majid al-Samubi al-Azhari. Ahkam al-Ahkam 'ala Tuhfat al-Ahkam fi al-Ahkam al-Syar'iyyah karya. MuMuhammad Yusuf al-Kafi. (Jaih.Mubarok, 2002, pp. 99-100)

Sedangkan kitab-kitab ushul fiqih dan qawaid al-figh aliran Malikiyah antara lain sebagai berikut: Syarah Tanqih al-Fushul al-Mashshul al-Ushul karya Syihab al-Din Abu al-Abbas bin Idris al-Qurafi. Al-Muwafaqat fi Ushul alAhkam karya Abi Ishaq Ibn Musa alSyathibi. Ushul al-Futiya karya Muhammad ibn al-Haris al-Husaini. AlFuruq karya Syihab al-Din Abu alAbbas Ahmad bin Idris al-Qurufi. Al- 
Robi Rendra Tribuana : Hukum Menikah Ketika Sakit Yang Menghalangi Keharmonisan Rumah Tangga Analisis Pendapat Imam Malik Bin Anas

DOI:10.24014/af.v18.i1.7098

Qawaid karya Al-Maqqawi. Idlah alMasalik al-Qawaid al-Imam Malik karya Al-Winsyarisi. Al-Is'af bi al-Thalab Mukhtashar Syarah al-Minhaj alMuntakhab karya Al-Tanawi. (Jaih.Mubarok, 2002, p. 100)

4. Apresiasi Ulama terhadap Imam Malik bin Anas

Imam Syafi'i berkata,"Malik aadalah guruku, darinya aku mengambil ilmu". Wahab bin Khalid berkata, "Tidak ada di antara timur dan barat seorang lelaki yang mengimani hadis rasulullah layaknya Imam Malik'. Diceritakan dari Imam Syafi'i, dia berkata, "Di bumi tidak ada kitab yang paling shahih dari pada Al-Muwaththa', karya Imam Malik".

5. Metode Istinbath Imam Malik bin

Anas

Metode istinbath Imam Malik dalam menetapkan hukum Islam adalah berpegang pada:Al-Qur'an,sunnah,ljma' ahl al Madinah, fatwa sahabat, khabar ahad dan qiyas, al- Istihsan,alMashlahah al-Mursalah, sadd al-zara'i, Istishhab, syar'u man qablana syar'un lana.

C. Penjelasan tentang Sakit

1. Pengertian Sakit

Sakit menurut bahasa adalah stigma (النقيصة - الوصمة),mengisap/pa rasit. Artinya sesuatu yang tidak sehat (ما يخلو عنه أصل الفطرة السليمة للشيء). (Maryam.binti.Isa.bin.Hamid.al-Issa, 1426/2005, p. 113) Menurut Istilah: (Maryam.binti.Isa.bin.Hamid.al-Issa, 1426/2005, p. 114)

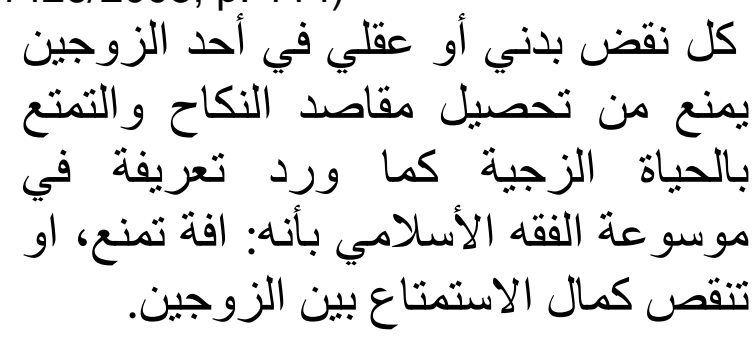

Artinya: "Setiap cacat fisik, atau pikiran salah satu pasangan, yang tidak bisa memenuhi tujuan dari pernikahan, dan menikmati kehidupan yang semestinya.Seperti yang dikadikatakan dalam ensiklopedi hukum Islam: yaitu yang mencegah dan mengurangi kenikmatan diantara pasangan".

Istilah sakit dalam bahasa Arab disebut مريض (Ahmad.Warson.alMunawwir,1997),yang artinya panda ngan seseorang bila merasa kesehatannya terganggu.Penyakit adalah istilah medis yang digambarkan se bagai gangguan dalam fungsi tubuh yang menghasilkan berkurangnya kapasitas. Penyakit terjadi pada saat keseimbangan dalam tubuh ti dak dapat dipertahankan.Adapun keadaan sakit terjadi pada saat seseorang tidak lagi berada dalam kondisi sehat yang normal. (Nadya, 2012)

Adapun sakit yang dimaksud dalam penelitian ini dalah sakit yang menghalangi keharmonisan rumah tangga,ialah penyakit yang membahayakan.Artinya, penyakit kronis yang biasanya berakhir pada kematian dan tidak bisa diobati atau disembuhkan lagi.

2. Pembagian penyakit

Para ulama fikih membedakan di antara penyakit yang bisa menyebabkan diperbolehkannya mem-fsakh nikah, yaitu:

a. Penyakit atau cacat yang Khusus Diderita Laki-laki yaitu :

1) Pengebirian/Jabb,menurut Maliki jabb adalah:

(Maryam.binti. Isa.bin.Hamid.alIssa, 1426/2005, pp. 132-133)

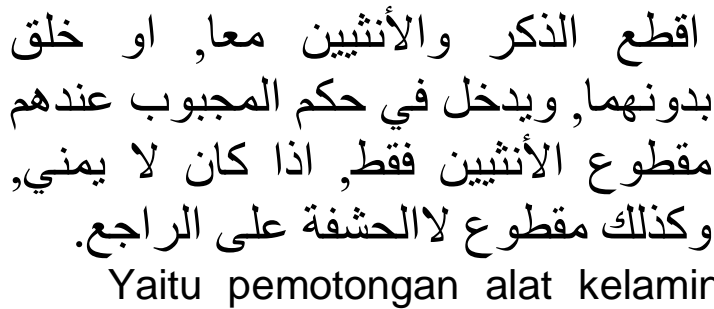
(penis) dan kedua testisnya. Menurut mayoritas ulama, cacat fisik akibat 
pemotongan kedua organ reproduksi ini bernilai sama dengan hanya memotong penis saja.

2) Impotensi/al-'inin adalah:

(Maryam.binti.Isa.bin.Hamid.al-

Issa, 1426/2005, p. 131)

مصدر عن، وعن الرجل عنه: عجز عن العن

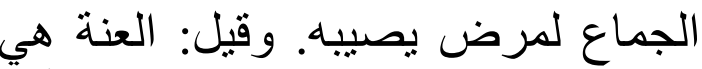

الحبس, العنين هو: الرجل لهبه الذي وفي لا يأتي

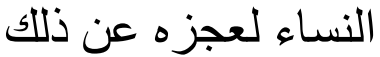

Di mana zakar laki-laki tidak hidup untuk jima' (Tihami, 2009, p. 147) atau juga dikenali sebagai impotensi,yaitu penyakit yang menyebabkan seorang laki-laki yang me nyandangnya tidak mampu melak sanakan tugas seksualnya.Dalam ke adaan seperti itu, menurut pendapat seluruh mazhab istri dapat memba talkan pernikahan.

(Muhammad.Jawad.Mughniyah, 2004, p. 351)

3) Al-Khisa', menurut Maliki adalah terpotongnya testis:

(Maryam.binti.Isa.bin.Hamid.alIssa, 1426/2005, p. 132)

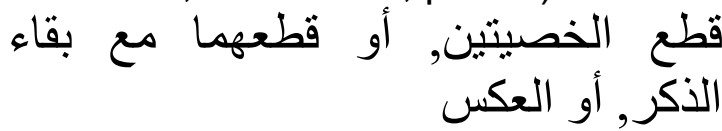

Yaitu menurut mayoritas ulama memotong, meremukkan, mencabut kedua testis, tanpa memotong penis. Menurut mazhab Maliki, al-khisa' adalah memotong penis tanpa me motong testis.

b. Penyakit atau cacat yang secara khusus diderita wanita

1) Ratq,adalah:

(Maryam.binti.Isa.bin.Hami d.al-Issa, 1426/2005, p. 134)

عرفه الفقهاء بعدة تعريفات كلها تدل

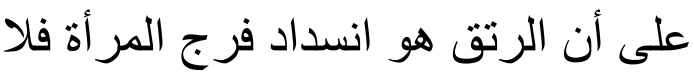

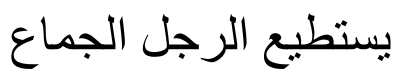

YaituAtersumbatnyaAlubangAse nggema sehingga tidak dapat di- fungsikan untuk melakukan hubungan intim.Gangguan seksual jenis ini bisa jadi disebabkan oleh sempitnya lubang vagina atau banyaknya daging pada daerah ini.

2) Qarn,menurut Maliki ada lah:

(Maryam.binti.Isa.bin.Hamid.al -Issa, 1426/2005, p. 134)

شيء يبرز في فرج المرأة يسبه قرن

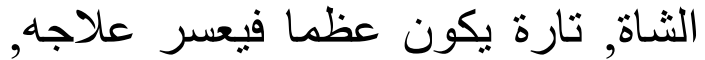
وتارة يكون لحما وهو الغالب, فلا يعسر علاجر علاجه ونارة

Yaitu adanya sesuatu yang menonjol dan menyumbat liang va gina sehingga menghalangi aktivitas hubungan intim. Benda menonjol ini bisa berbentuk daging atapun tulang. Qarn juga tumbuh pada kelaminwa nita yang berbentuk tanduk domba .(Muhammad.Jawad.Mughniyah, 2004, p. 147)

3) 'Afal menurut Maliki adalah: (Muhammad.Jawad.Mughniyah, 2004, p. 135)

لحم يبرز في فرز المر اة يشبه أدرة الرجل التي انتفاخ الخصية

Yaitu munculnya busa dalam vagina yang terjadi ketika melakukan hubungan seksual.

c. Penyakit atau Cacat yang

Diderita Laki-Laki dan Wanita

1) Gila/Al-janun:

(Muhammad.Jawad.Mughniyah, 2004, pp. 136-137)

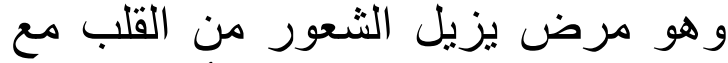

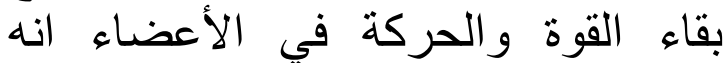
اختلال العقل بحيث يمنع جريا الأفعال الأله والأقوال على نهجه الال نادر ا.

Penyakit ketidaknormalan dalam cara berpikir dan berperilaku yang kurang wajar. Maliki, Syafi'i, dan 
Robi Rendra Tribuana : Hukum Menikah Ketika Sakit Yang Menghalangi Keharmonisan Rumah Tangga Analisis Pendapat Imam Malik Bin Anas

DOI:10.24014/af.v18.i1.7098

Hambali sepakat bahwa suami boleh mem-fasakh-kan akad pernikahan karena penyakit gila yang diderita istrinya, demikian pula sebaliknya. (Muhammad.Jawad.Mughniyah, 2004, p. 335)

2) Penyakit kusta atau judzam adalah: (Maryam.binti.Isa.bin.Hamid.al-Issa, 1426/2005, p. 136)

$$
\begin{aligned}
& \text { علة يحمر منها العضوم ثخم يتقطع } \\
& \text { ويتناثر ويتصور ذلك في كل عضو } \\
& \text { لكفة في الوجه أغلب ولتبانب }
\end{aligned}
$$

Yaitu cacat yang terjadi akibat penyebaran bercak hitam ada sekujur tubuh. Penyakit ini merusak resam dan organ tubuh. Besar kemungkinan penyakit ini berakhir dengan kerapuhan organ tubuh,sehingga organ tubuh terlepas dan diiringi dengan pembusukan. adalah:

3) Penyakit lepra atau barash

(Maryam.binti.Isa.bin.Hamid.al-Issa, 1426/2005, p. 137)

وهويته بياض شديد يبقع الجلد ويز هب

Yaitu munculnya bercak putih pada permukaan kulit dan merusak resam tubuh,bercak-bercak putih semakin lama semakin besar. Seringkali pada bercak putih ini ditumbuhi bukubuku putih atau bisa jadi bercak yang ditimbulkan berwarna hitam.

\section{Penyakit (cacat) Tersembunyi yang Dinyatakan dan tidak Di nyatakan}

Para ahli fikih mengemukakan dua syarat bagi masing-masing (suami istri) untuk mengajukan hak gu gatan perceraian (fasakh) atas dasar penyakit atau cacat yang diderita pasangannya:(a) Pada saat terjadinya akad nikah pihak yang menuntut fasakh ini tidak mengetahui penyakit atau cacat yang dijadikan alasan perceraian (fasakh). (b) Orang yang mengajukan gugatan cerai ini tidak dapat menerima penyakit atau cacat yang diderita pasangannya setelah akad nikah dilangsungkan.

\section{METODE PENELITIAN}

Penelitian ini adalah penelitian penelitian pustaka (libraryresearch).. Penelitian ini bersifat deskriptif analitis. Jenis data penelitian ini adalah primer, sekunder,danAtersier.TeknikApengum pulan data melalui: Pertama, Studi kepustakaan atau observasi literatur. Kedua, literatur-literatur yang ada diklasifikasikan sesuai dengan hubungannya dengan penelitian. Ketiga, setelah itu dilakukan penelitian, yakni dengan cara membaca, mempelajari, atau mengkaji literatur-literatur yang mengemukakan masalah-masalah yang berkaitan dengan penelitian. Teknik analisa data yang digunakan adalah teknik content analysis (an alisa isi) dengan metode kualitatif menggunakan analisa deskriptif.

\section{HASIL PENELITIAN DAN PEMBA HASAN}

\section{A. Sakit Yang Menghalangi \\ Keharmonisan Rumah Tangga.}

Sakit/cacat nikah menurut bahasa adalah stigma (النقيصة - الوصدة), mengisap/parasit. Artinya sesuatu yang tidak sehat ( ما يخلو عنه أصل الفطرة السليمة (للثيء). (Maryam.binti.Isa.bin.Hamid.alIssa, 1426/2005, p. 137)Sakit/cacat nikah menurut Istilah:

(Maryam.binti.Isa.bin.Hamid.al-Issa, 1426/2005, p. 114)

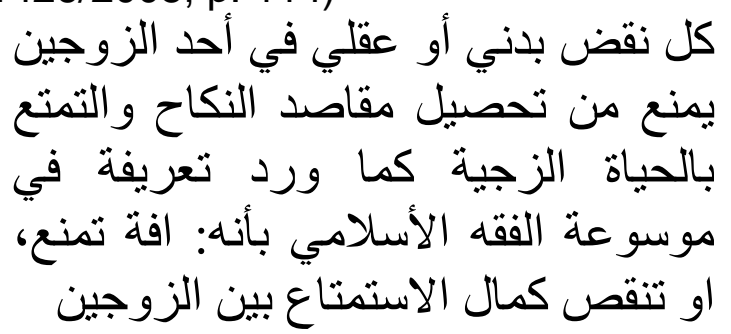

Setiap cacat fisik, atau pikiran salah satu pasangan, yang tidak bisa memenuhi tujuan dari pernikahan, dan menikmati kehidupan yang semesti 
nya. Seperti yang dikatakan dalam ensiklopedi hukum Islam: yaitu yang mencegah dan mengurangi kenikmatan di antara pasangan.

Pembahasan tentang hukum ketika menikah sakit,disamakan dengan menikah ketika sakit yang menghalangi keharmonisan rumah tangga, yang juga berkaitan dengan fasakh. (Sayyid.Sabiq, 2006, p. 627) yang menyebabkan fasakh adalah kecacatan/aib, seperti: impotensi, gila, karena penyakit sopak dan kusta, karena al-ratq, al-qarn, al-afal dan alifdha'.Adapun aib yang dimaksud adalah aib yang menghalangi perse tubuhan.

Ma'qil bin Yasar ra.menyataka n bahwa Nabi saw.bersabda:

(Sulaiman.bin.al-

'Asy'asy.ABu.Daud.as-Sijistani, 2002, p. 228)

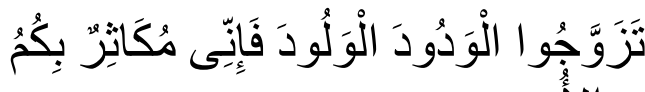

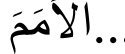

Artinya:"...Menikahlah dengan wanita yang besar kecintaannya dan banyak melahirkan (subur kandung annya).Sesungguhnya Aku mengun gguli umat-umat lain dengan (jumlah) kalian". (HR. Abu Daud dan Nasa'i)

Dalam hadis di atas al-wadud berarti wanita yang sangat menyayangi suaminya, sedangkan al-walud adalah wanita yang berpotensi me -lahirkan banyak anak.

B. Pendapat Malik bin Anas tentang Menikah ketika Sakit yang Menghalangi Keharmonisan Rumah Tangga

Adapun pendapat Imam Malik bin Anas tentang hukum menikah ketika sakit, dapat dilihat dalam kitab AlMudawwanah al-Kubro:

(Imam.Sahnun.bin.Said.at-Tanwahi, tt, p. 182).

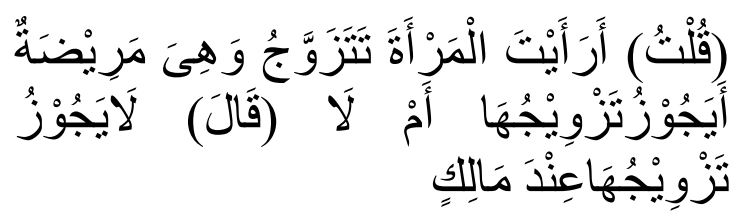

Artinya:"Aku (Asad bin Furat) bertanya: 'Bagaimana pendapatmu (Ibnu alQasim) perempuan menikah padahal ia dalam keadaan sakit,apakah per nikahannyaAbolehAatau tidak'? Dia (Ibnu al-Qasim) berkata: 'Tidak boleh menikahi perempuan tersebut menurut pendapat Imam Malik".

Dilihat dari konteks di atas, dapat dipahami bahwa Imam Malik bin Anas berpendapat tidak boleh menikah dalam keadaan sakit. Kata la yajuz lawan kata dari jaiz, di mana kata la yajuz dalam pendapat Imam Malik bin Anas ini hukumnya mendekati haram, karena akibat hukum yang ditimbul kannya.Apabila terjadi pernikahan maka tidak ada saling mewarisi jika salah satunya meninggal dunia. Imam Malik bin Anas menegaskan pendapatnya: (Imam.Sahnun.bin.Said.atTanwahi, tt, p. 182)

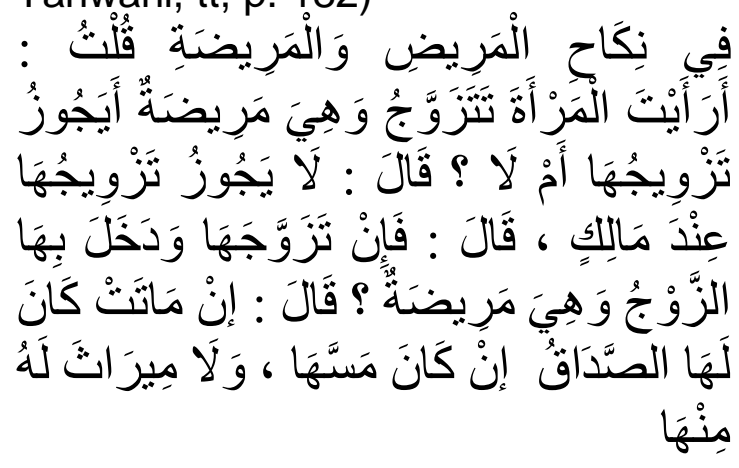

Artinya:"Menikah ketika dalam kead aan sakit: (Aku berkata), "Bagaimana menurut kamu perempuan menikah padahal ia dalam keadaan sakit? Apakah pernikahannya boleh atau tidak"?(Dia berkata), "Tidak bolehme nikahi perempuan tersebut menurut pendapat Imam Malik."(Dia berkata ), "Maka jika seseorang menikahinya dan berhubungan badan dengannya padahal perempuan itu sedang sakit", (Dia berkata), "Jika perempuan itu 
Robi Rendra Tribuana : Hukum Menikah Ketika Sakit Yang Menghalangi Keharmonisan Rumah Tangga Analisis Pendapat Imam Malik Bin Anas

DOI:10.24014/af.v18.i1.7098

meninggal maka baginya maskawin dan tidak ada warisan dari perempuan tersebut".

Dari pernyataan di atas dapat dipahami bahwa Imam Malik bin Anas berpendapat tidak ada warisan dari perempuan tersebut jika menikah ketika sakit,ketika perempuan terse but meninggal.Hal ini juga dapat dilihat dalam uraian berikut ini: (Imam.Sahnun.bin.Said.at-Tanwahi, tt, p. 182)

(قلت ) أرأيت ان تزوّج فى مرضنه ودخل

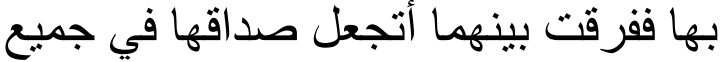

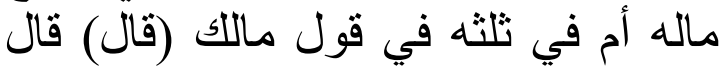

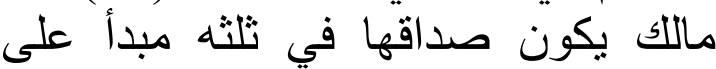

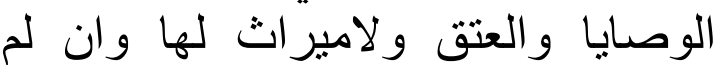

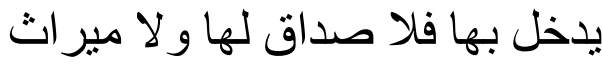

Artinya: "Aku berkata (Asad bin Furat) apa pendapatmu jika seorang laki-laki menikah saat sakit dan berhubungan badan dengan istrinya, kemudian keduanya berpisah (cerai), apakah maharnya pada seluruh harta suami atau 1/3-nya menurut pendapat Malik"? (Ibnu al-Qasim berkata:)'Malik berkata: mahar baginya pada 1/3 harta suami tanpa mewarisi darinya.Adapun jika belum terjadi persetubuhan maka tidak ada mahar maupun waris".

Dari konteks di atas dapat di pahami bahwa Imam Malik bin Anas berpendapat,jika tejadi pernikahan ketika sakit,kemudian mereka bepisah, maka mahar orang yang menikah ketika sakit itu adalah sepertiga harta suaminya jika bersetubuh, dan jika belum, maka tidak ada mahar baginya (istri).

Sebagaimana yang telah disebutkan di atas, bahwa aib pada diri suami adalah Impotensi/al'inin: (Maryam.binti.Isa.bin.Hamid.al-Issa, $1426 / 2005$, p. 131)

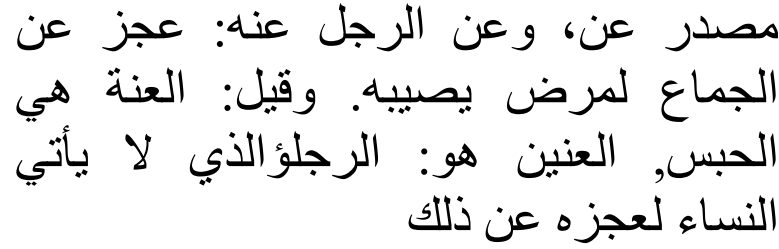

Impotensi ini terpotongnya tulang yang menyebabkan tidak mampunya seorang lelaki melakukan hubungan suami istri

(Mansur.bin.Yunus.bin.Idris.al-Bhuty, 1983) sebab zakar lelaki tersebut lemas hanya bergerak ke kanan dan ke kiri farj wanita karena suatu pe nyakit atau memang lemah.Sedang kan menurut Malikiyah, kecilnya zakar sehingga tidak mungkin untuk masuk dan terbenam.

(Abu.al-

Qasim.Muhammad.bin.Ahmad.Juzai.a I-Kalbi.al-Ghamaty.al-Maliki, tt, p. 354) Imam Malik bin Anas sepakat bah wa impotensi yang diderita suami memberikan khiyar (pilihan)kepada istri untuk membatalkan akad.

(Muhammad.lbrahim.Jannati, 2007, pp. 345-346)

Adapun Al-Khisa' menurut Ma liki adalah terpotongnya testis:

(Maryam.binti.Isa.bin.Hamid.al-Issa, 1426/2005, p. 132)

$$
\text { العكع الخصيتين, أو قطعهما مع بقاء الذكر, أو }
$$

Al-khisa'juga dapat diartikan terpo terpotongnya dua buah pelir atau hilangnya keduanya karena pecah atau kebiri.

(Abu.Abdillah.bin.Ahmad.bin.Muhamm ad.Qudamah.al-Maqdisi, 1997, p. 58)

Terpotongnya kelamin $(j a b b)$ dan pengebirian. (Ibnu.Mandhur, 2009, p. 187) Menurut Maliki jabb adalah: (Maryam.binti. Isa.bin.Hamid.al-Issa, 1426/2005, pp. 132-133)

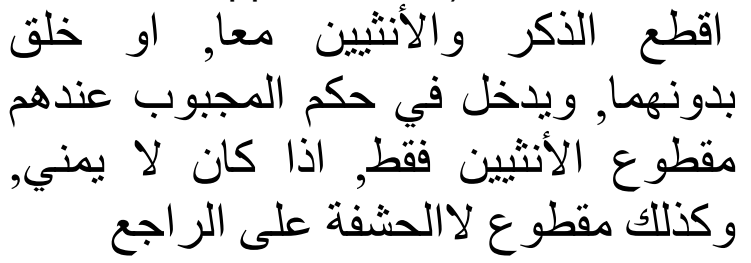


Terpotongnya buah zakarnya atau hanya pelirnya saja.Adanya pada seorang laki-laki.Menurut Kesepakatan semua ulama mazhab menye menyebabkan seorang istri dapat membatalkan pernikahan,tanpa keharusan menunggu bila hal itu sudah ada sebelum hubungan seksual.Se -dangkan bila hal tersebut baru terjadi setelah akad nikah dan telah me lakukan hubungan seksual, maka si istri tidak berhak membatalkan per nikahan. (Mhmd.Jawad.Mughniyah, 2004, p. 352)

Terdapat dua hal yang perlu dijelaskan di sini: Pertama, selama suaminya tidak bisa ejakulasi, istri tetap memiliki khiyar untuk memba talkan akad, baik suami bisa ereksi ataupun tidak. Sebab, tidak dapat ejakulasi adalah sebuah aib dan cela seperti halnya impotensi.

(Abdurrahman.al-Jaziri, 1979, p. 818) Selain itu, dalil juga menunjukkan secara mutlak atas khiyar istri untuk membatalkan akad bila suaminya dikebiri.Kedua, menurut Maliki bila istri membatalkan akad karena kelamin suaminya terputus, dia tidak berhak atas mahar,karena hubungan badannya tidak terjadi. Bila disebabkan oleh kebiri,dia berhak atas mahar bila dicampuri dan tidak berhak atas mahar bila suaminya tidak menca mpurinya. (Muhmad.Ibrahim.Jannati, 2007, p. 385)

Adapun aib yang terdapat pada diri istri adalah: Ratq, menurut fuqaha ratq adalah:

(Maryam.binti.Isa.bin.Hamid.al-Issa, 1426/2005, p. 134)

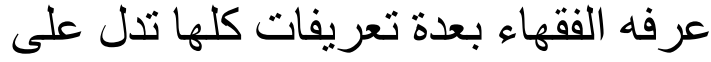

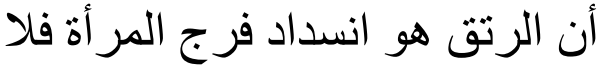

$$
\begin{aligned}
& \text { يسنطيع الرجل الجماع النداع }
\end{aligned}
$$

Penyumbatan vagina wanita,sehingga priaAtidakAdapatAmelakukanAhu bungan intim. Dapat juga diartikan, tertutupnya lubang vagina sehingga menyulitkan hubungan badan. Qarn, yaitu sesuatu seperti gigi yang muncul di dalam vagina yang menghalangi hubungan badan.

'AfI menurut Maliki adalah:

(Maryam.binti.Isa.bin.Hamid.al-

Issa, 1426/2005, p. 135)

لحم يبرز في فرز المر اة يثبه أدرة الرجل التي انتفاخ ألخصية فرز الترن

Daging yang menonjol di vagina wanita yang menyerupai tinju pria, yaitu tumbuhnya daging di vagina yang menghalangi proses hubungan badan.

Para pakar bahasa dan ahli fikih berbeda pendapat apakah 'afl berbeda dengan qarn atauAtidak (mayoritas mengatakan bahwa keduanya sama).Ifdha', yaitu pemisah antara lubang kencing dan lubang haid. Sebagian mengartikannya dengan bersatunya lubang kencing dan lubang haid.Menurut mazhab Maliki inilah empat aib yang ada pada diri wanita yang memberikan khiya kepada suami untuk membatalkan akad. (Muhammad. Ibrahim.Jannati,2007,pp. 385-386)

Sedangkan aib yang ada pada diri suami dan istri adalah sebagai berikut:Kegilaan/al-janun:

(Maryam.binti.Isa.bin.Hamid.al-Issa, 1426/2005, pp. 136-137)

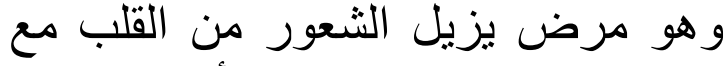
بقاء القوة والحركة في الأعضاء، انهاب النها

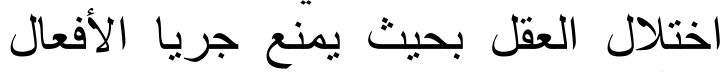
و الأقوال على نهجه الان نادر ا.

Penyakit yang menghilangkan kepekaan perasaan, ketidaknormalan dalam cara berpikir dan berperilaku yang kurang wajar,serta ketidak seimbangan pikiran dan tindakan.

Menurut mazhab Maliki, suami dapat membatalkan akad bila istrinya gila dan begitu pula sebaliknya, istri 
Robi Rendra Tribuana : Hukum Menikah Ketika Sakit Yang Menghalangi Keharmonisan Rumah Tangga Analisis Pendapat Imam Malik Bin Anas

DOI:10.24014/af.v18.11.7098

dapat memililih membatalkan akad bila suaminya gila. (Ibnu.Rusyd, 1990, p. 51) Adapun penyelesaiannya adalah: Pertama, mazhab Maliki mengatakan, bila penyakit gila muncul sebelum akad maka keduanya berhak untuk mem batalkannya, dengan syarat bahwa yang waras merugi bila dia tetap hidup bersama dengan si gila.Apabila penyakit ini muncul setelah akad, bahwa hanya istri yang berhak mebatalkan akad setelah hakim memberinya waktu selama satu tahun Qamariyah, karena mungkin suaminya bisa sembuh dalam jangka waktu ini. Sementara suami tidak berhak membatalkan akad, bila istrinya menjadi gila setelah akad. (Abdul.Rahman.bin.Muhammad.'Audh. al-Jaziri, 2001, p. 818) Kedua, mazhab Maliki mengatakan bahwa apabila su ami membatalkan akad sebelum me ncampuri istrinya, maka si istri tidak berhak atas mahar.Bila setelahnya, maka dia berhak atas mahar musa $m m a$. Begitu pula halnya bila istri yang membatalkan akad.

Sopak (barash) adalah: (Maryam.binti.Isa.bin.Hamid.alIssa, 1426/2005, p. 137)

وهو بياض شديد ييقع الجلد ويزهب دمويته

Munculnya bercak putih pada permukaan kulit.

Kusta (judzam) adalah: (Maryam.binti.Isa.bin.Hamid.alIssa, 1426/2005, p. 136)

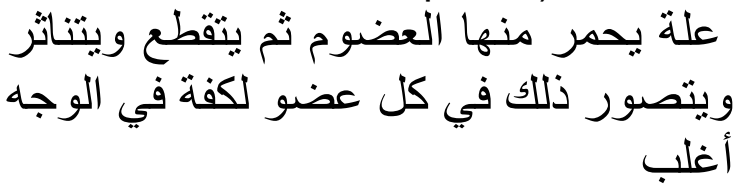

Cacat yang terjadi akibat penyebaran bercak hitam ada sekujur tubuh. Penyakit ini merusak resam dan organ tubuh.

Al-basur adalah:

(Maryam.binti.Isa.bin.Hamid.alIssa, 1426/2005, pp. 137-138)

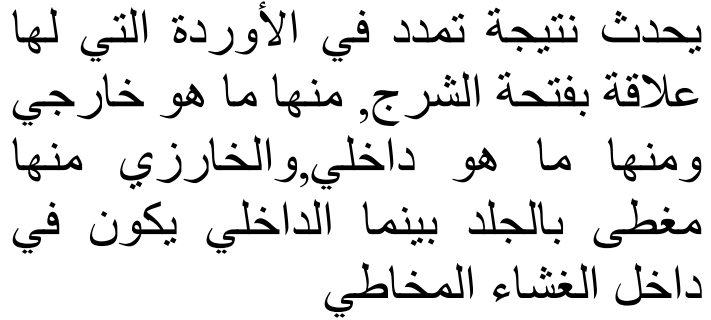

Kondisi di mana pembuluh darah vena di sekitar anus meradang atau bengkak.Wasir dapat muncul di dalam rektum (saluran yang menghubung kan usus besar dengan anus) atau di sekitar anus (dubur).

Menurut mazhab Maliki termasuk aib atau cela yang terdapat pada diri suami dan pada diri istri, di mana masing-masing bisa membatalkan akad bila melihat aib ini ada pada pasangannya.Mazhab Maliki ber pendapat,istri dapat membatalkan akad bila suaminya tertimpa sopak sebelum dan setelah akad.Sedangkan suaminya bisa membatalkan akad bila istrinya terkena sopak sebelum akad dan pada saat akad. Bila kusta menimpa sebelum akad, maka keduaduanya berhak membatalkan akad. Bila muncul setelah akad, maka hal membatalkan akad hanya untuk istri dan tidak mencakup suami.

Adapun yang dimaksud sakit di sini adalah penyakit yang menghalangi keharmonisan rumah tangga. Jika hal itu terjadi, maka pernikahan dibatalkan sekalipun setelah terjadi persanggamaan, kecuali jika orang yang sakit tersebut sembuh sebelum pernikahannya dibatalkan. Jika belum terjadi persanggamaan maka si pe rempuan tidak berhak mendapatka mahar. (Wahbah.az-Zuhaily, al-Fiqhul Islamy, tth, p. 83)

Istinbath hukum yang dipakai Imam Malik bin Anas dalam mene tapkan mahar orang yang menikah ketika sakit adalah $1 / 3$ harta, yaitu fatwa sahabat dari Ibnu Wahab yang diriwayatkan oleh Laits: 
(Imam.Sahnun.bin.Said.at-Tanwahi, tt, p. 186)

$$
\begin{aligned}
& \text { عَنْ الليث بن سعد عن يحيى بن سعيد }
\end{aligned}
$$

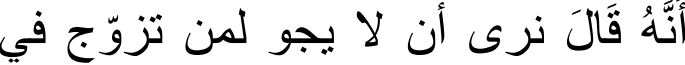

$$
\begin{aligned}
& \text { مرض صداق الاف تثلث المال. }
\end{aligned}
$$

Artinya: "Ibnu Wahab) dari Laits bin Sa'ad dari Yahya bin Sa'id bahwa ia berkata: 'Kami melihat bahwa tidak bolehnya bagi seseorang yang menikah saat sakit memberi mahar kecuali 1/3 dari harta"'.

PenetapanAistinbathAhukum memberi mahar $1 / 3$ harta jika terjadi pernikahan adalah meng-qiyas-kan nikah dengan hibah,karena pernikahan dalam penyakit yang membah ayakan merupakan bentuk pemberian (hibah), sedangkan hibah orang yang sedang sakit itu tidak boleh kecuali dari sepertiga harta. (Ibnu.Rusyd, 1990, p. 446)

Mengenai pendapat Imam Malik bin Anas tentang tidak ada saling mewarisi jika terjadi pernikahan dalam keadaan sakit, beliau menggunakan fatwa sahabat, yaitu dari Ibnu Wahab yang diriwayatkan oleh Ibnu Syihab: (Imam.Sahnun.bin.Said.at-Tanwahi, tt, p. 186)

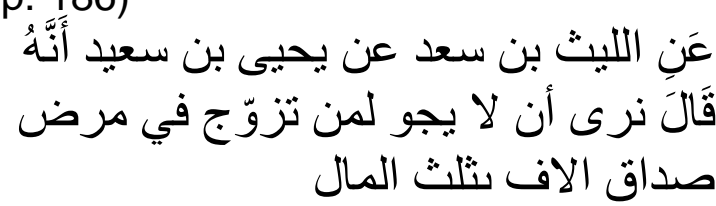

Artinya: "(Ibnu Wahab) dari Laits bin Sa'ad dari Yahya bin Sa'id bahwa ia berkata: "kami melihat bahwa tidak bolehnya bagi seseorang yang menikah saat sakit memberi mahar kecuali 1/3 dari harta".

Pernikahan orang yang sakit yang menghalangi keharmonisan rumah tangga, menurut Malikiyah dia tidak ada saling mewarisi, karena memasukkan ahli waris dalam tirkah (harta warisan) yang tidak ada ketika masih sakit. (Wahbah.az-Zuhaily, alFiqhul Islamy, tth, p. 111)
C. Relevansi Pendapat Malik bin Anas tentang Menikah ketika Sakit yang Menghalangi Keharmonisan Rumah Tangga dengan Kondisi saat ini

Pendapat Imam Malik bin Anas tentang pernikahan ketika sakit yang menghalangi keharmonisan rumah tangga dihubungkan dengan konteks pernikahan di Indonesia. Sepanjang data yang dicari dan dilacak, tidak terdapat peraturan perundangundan gan mengenai perkawinan yang mengatur pernikahan ketika sakit ini.

Dalam Pasal 1 Undang-Undang Nomor 1 Tahun 1974 terdapat dua kunci utama: Pertama, perkawinan adalah ikatan lahir batin, yaitu ikatan yang kokoh dilakukan bukan untuk dibubarkan.Ketentuan ini tidak sejalan dengan pernikahan ketika sakit yang mengahalangi keharmonisan rumah tangga. Hal ini dikarenakan di antara pasangan suami istri hanya salah satu yang akan bisa melakukan hak dan kewajiban, sedangkan yang sakit tidak bisa melakukan hak dan kewajiban nya.Sehingga lambat laun akan mengikis ikatan perkawinan di antara kedunya.Kedua, dalam salah satu ayat yang lain terdapat ketentuan bahwa tujuan untuk membentuk ke luarga atau rumah tangga yang berbahagia dan kekal berdasarkan Ketuhanan Yang Maha Esa. Dalam ketentuan ini terdapat kata yang tidak sejalan dengan pernikahan ketika sakit dilakukan karena dikhawatirkan umur pernikahan hanya dalam waktu singkat.

Di dalam Kompilasi Hukum Islam sebenarnya belum ada penjelasan tentang hukum permasalahan perni kahan ketika sakit yang menghalangi keharmonisan rumah tangga. Namun, dapat dijadikan pedoman dalam Pasal 2 Kompilasi Hukum Islam dan pe mbahasan sakit yang mengehalangi 
Robi Rendra Tribuana : Hukum Menikah Ketika Sakit Yang Menghalangi Keharmonisan Rumah Tangga Analisis Pendapat Imam Malik Bin Anas

DOI:10.24014/af.v18.11.7098

keharmonisan rumah tangga,ditetap kan bahwa perkawinan adalah akad yang mempunyai daya ikat yang sangat kuat atau mitsaq ghalizha.

Oleh karena itu, pasal ini juga dapat dijadikan alasan bahwa menikah ketika sakit tidak sejalan dengan Kompilasi Hukum Islam, karena ikatan menikah ketika sakit diprediksi bersifat sementara (tidak kuat atau tidak mitsaq ghalizham).

Namun penyakit apapun itu,apabila bisa dipulihkan atau diobati tanpa meninggalkan bekas yang serius,maka penyakit tersebut dian ggap tidak ada dan tidak berpengaruh apapun terhadap akad. Akan halnya tentang perhatian para ulama mazhab khususnya Imam Malik bin Anas yang demikian tinggi terhadap cacat-cacat serupa itu sejak beberapa kurun waktu yang lalu, adalah karena belum adanya teknologi penyembuhan dan pengobatan seperti masa modern sekarang ini, seperti operasi bedah plastik dan lain sebagainya.

\section{Kesimpulan}

Berdasarkan hasil penelitian yang telah dilakukan berhubungan dengan masalah tesis ini, maka dapat ditarik kesimpulan bahwa: Sakit yang menghilangkan keharmonisan di da lam rumah tangga diqiyaskan atau disamakan dengan aib yang meny ebabkan fasakh nikah. Aib tersebut adalah:impotensi,jabb/pengebirian, rat afl, khisa', gila, sopak, kusta.Pendapat Imam Malik bin Anas tentang menikah ketika sakit yang menghalangi keharmonisan rumah tangga adalah akad nikah boleh dibatalkan/cerai. Adapun untuk kondisi di zaman sekarang, bahwasanya penyakit/cacat apapun itu, apabila bisa dipulihkan atau diobati tanpa meninggalkan bekas yang serius, maka penyakit tersebut dianggap tidak ada dan tidak berpengaruh apapun terhadap akad.
Akan halnya pandangan Imam Malik bin Anas yang demikian tinggi terterhadap cacat-cacat serupa itu sejak beberapa kurun waktu yang lalu adalah karena mereka belum adanya teknologi penyembuhan dan pengo batan seperti masa modern sekarang ini.

\section{DAFTAR PUSTAKA}

Bhuty, Mansur bin Yunus bin Idris alBhuty, Kasyiful Qina' Matan al Iqna', Jilid 5, Beirut: al 'Alam alKutub, 1983.

Dinar, Abu Hasan Ali bin Umar bin Ahmad bin Muhadi bin Mas'ud bin Nu'iman bin, Sunan alDaruquthni, Juz VIII, Beirut: Dar al-Hadist Kairo, t.th.

Djumadris, M. Bahri Ghazali dan, Perbandingan Madzhab, Jakarta: Pedoman IImu Jaya, 1992.

Issa, Maryam binti Isa bin Hamid, Bukti Cacat Nikah dengan Medis, Jurnal Penelitian Yurisprudensi Kontemporer, Vol. 27, No. 103, $1426 \mathrm{H}$.

Jannati, Muhammad Ibrahim, Fiqih Perbandingan Lima Mazhab: Syafi'i-Hambali-Maliki-HanafiJa'fari, Jilid III, alih bahasa Ibnu Alwi Bafaqih, Mudhor Assegaf, dan Alam Firdaus, Cet. ke-1, Jakarta Selatan: Cahaya, 2007.

Jaziri, Abdurrahman, Al-Fiqh 'ala Madzhaib al-Arba'ah, Juz 4, Qairo: Maktabah al-Tijarah Kubrah, 1400H/1979M.

Jaziri, Abdul al-Rahman bin Muhammad 'Audh, Al-Fiqh 'ala al-Madzahib al'Arba'at, Beirut: Dar ibn Hazm, 2001.

Kandahlawi, Maulana Zakariya, AlMuwaththa', t.th.

Kholil, Moenawar, Biografi Empat Serangkai Imam Madzhab, Cet. ke-8, Jakarta: Bulan Bintang, 1992. 
Maliki, Abu al-Qasim Muhammad bin Ahmad Juzai al-Kalbi alGharnaty , Al-Qawanin alFikhiyah fi Ta'khis Mazhab alMalikiyah, t.tp: tp, t.th.

Maqdisi, Abu Abdillah bin Ahmad bin Muhammad Qudamah, AlMughni, Jilid 10, Riyadh: Dar Alam al-Kutub, 1997.

Mubarok, Jaih, Sejarah dan Perkembangan Hukum Islam, Bandung: PT. Remaja Rosdakarya, 2002.

Mughniyah, Muhammad Jawad, Fikih Lima Mazhab, alih bahasa Masykur AB., Jakarta: PT. Lantera Baristama, 2004.

Munawwir, Ahmad Warson, Kamus alMunawwir Arab-Indonesia Terlengkap, Yogyakarta: Pustaka Progresif, 1997.

Nadya, Konsep Sehat dan Sakit, Artikel Peserta Orientasi IDI Tahun 2012. Dokumen Pusat Peningkatan \& Penajaminan Mutu UIN Alauddin.

Nurwahid, Haswir dan Muhammad, Perbandingan Mazhab, Realitas Pergulatan Pemikiran Ulama Fiqih, Pekanbaru: Alaf Riau, 2006.

Qazwini, Abu Abdullah Muhammad bin Yazid bin Majah, Sunan Ibnu Majah, Juz VI, Mesir: Dar Ihya'il Kutub al-Arobiyah, t.th.

Rusyd, Ibnu, Bidayatu'l Mujtahid, alih bahasa M.A. Abdurrahman dan A. Haris Abdullah, Semarang: CV. Asy-Ayifa', 1990.

Rusyd, Ibnu, Bidayatul Mujtahid 2, alih bahasa Ahmad Abu al-Majdi, Jakarta Selatan: Pustaka Azzam Anggota IKAPI DKI, 2014.

Sabiq, Sayyid, Fiqih Sunnah 2, alih bahasa Nor Hasanudin, Cet. ke-1, Jakarta: Pena Pundi Aksara 2006.
Sijistani, Sulaiman bin al-'Asy'asy bin Syadid bin 'Umaru al-'Azadi Abu Daud, Sunan Abu Daud, Bab Larangan Menikah, Juz VI, Beirut: Dar al-basyair alIslamiyah, 2002.

Syarifuddin, Amir, Hukum Perkawinan Islam di Indonesia, Jakarta: Kencana, 2011.

Tanwahi, Imam Sahnun bin Sa'id, Mudawwanah al-Kubro, Juz II, Beirut: Dar al-Fikr, t.th.

Tihami, Fiqih Munakahat, Jakarta: Rajawali Press, 2009.

Yanggo, Huzaemah Tahido, Pengantar Perbandingan Mazhab, Jakarta : Logos, 1997.

Zuhaily, Wahbah, Al-Fiqhul Islami wa 'Adilatuhu, Juz II, Beirut: Dar alFikr. T.th.

Zuhaily, Wahbah, Al-Figh al-Islami wa Adillatuhu, Jilid VII, Damaskus: Dar al-Fikr, t.th..

Zuhaily, Wahbah, Fiqih Islam wa Adillatuhu, alih bahasa Abdul Hayyie al-Kattani, dkk., Jakarta: Gema Insani, 2011.

Zein, Muhammad Ma'sum, Arus Pemikiran Empat Madzhab, Jatim: Darul-Hikmah, 2008.

Zulkayandri, Fikih Muqaran, Program Pascasarjana UIN Suska Riau, 2008. 